based on a materialistic philosophy. The religious mysticism of pre-War Russia has now been replaced by the mysticism of the machine. The conception of science in Soviet Russia is that of an auxiliary to socialism. Education figures as a definite part of the Five Years Plan, and the Educational Plan comprises a general scheme of public education, the preparation of technicians and scientific workers from among the working classes, together with a general scheme of scientific research and the establishment of numerous scientific institutes. The author describes a number of these institutes which he visited, including the physico-technical "Kombinat" at Leningrad with its subsidiary institutes of physical chemistry and electro-physics. In addition, it has an experimental workshop of a unique character which manufactures scientific instruments for the "Kombinat" and other institutes. Employing about 300 workers, it is a half-industrial and halfscientific organisation. Soviet industry has thus behind it very extensive means for scientific research, and the various problems, classified according to interest or urgency, are investigated by the specialised chemical, physical or electrical institutes.

\section{Chemical Researches in Czechoslovakia}

Ever since the middle of last century, much chemical research work has been carried out at Prague. Some of the investigations, notably Prof. B. Brauner's work on atomic weights and on the rare earth elements, attracted wide attention, but much valuable, if less spectacular, work was overlooked. Few Czech men of science published in English journals; the majority of their researches appeared in the little-read Czech publications. To direct more attention to their achievements, Czechoslovak chemists founded in 1928 under the joint editorship of Profs. Votoček and Heyrovský the Collection of Czechoslovak Chemical Communications, in which the contributions were written in French or English. Among the more interesting contributions that have appeared recently in this journal mention may be made of the diseovery by Prof. Křepelka and Dr. Novotný that mercurous halides show marked triboluminescence, the actual intensity depending on the conditions of preparation. Prof. Simek has also made some observations on the curious electrical behaviour of fused tellurium dioxide. In organic chemistry, Drs. Landa and Machaček have described a new solid hydrocarbon, $\mathrm{C}_{10} \mathrm{H}_{16}$, to which they assign the name adamantane. A series of researches by Prof. Votoček and his collaborators has cleared up a number of points in connexion with the lesserknown sugars such as rhamnose, rhodeose and fucose. Prof. Heyrovský has also published a series of papers (referred to in NatuRE of March 10, p. 385) dealing with his polarographic studies with the dropping mercury cathode.

\section{The Indian Chemical Society (1924-1932)}

Prof. B. K. Singh's presidential address to the Indian Chemical Society (Journal of the Indian Chemical Society, vol. 10, No. 1, p. 1, 1933) deals with
"Optics in the Service of Chemistry", and includes a review of recent work on optical rotatory power and rotatory dispersion, to which he has himself con. tributed. He also records in a tabular form the growth of the Indian Chemical Society, during the nine years of its existence. During the first five years the growth was rapid, but the Society has held its own during the more difficult years from 1929 until 1932. It now includes 360 fellows and 100 subscribers, and is publishing approximately 100 papers in each year, of which 750 pages are printed free of cost by the University of Calcutta. Under these favourable conditions an income of about $10,000 \mathrm{Rs}$. has usually provided a credit balance, and a reserve fund of $21,000 \mathrm{Rs}$. has been built up, in addition to a donation of $10,000 \mathrm{Rs}$. from Sir P. C. Rây which is earmarked for the provision of a headquarters for the Society.

\section{Schlieren, Striæ or Streaks?}

IN the January issue of the Journal of Scientific Instruments, Mr. T. Smith, of the National Physical Laboratory, raises the question whether it is fair to Foucault to continue to describe the method he introduced for observing small optical differences of path by the name "schlieren" used for the method by Töpler in his paper of 1866 on the motion of singing flames. Messrs. Taylor and Waldram, who had used the term 'schlieren' in their paper in the December issue of the Journal, point out that Töpler in giving the method that name made no claim to its invention but only to an extension of the use of it to general scientific investigations. Would striæ or streaks be adequate equivalents of, and suitable alternatives for, schlieren?

\section{Uniformity in Bibliographical Particulars}

REFERRING to recent correspondence on this subject (Nature, 133, 380, March $10 ; 495$, March 31, 1934), Mr. A. Windelbandt, bibliographer in the library of the Institute of Plant Industry, Leningrad, writes pointing out the practical value of accurately given bibliographical citations in articles and books. Mr. Windelbandt states that footnotes and other references are often given in such a way as to make it impossible to recognise the publication. While the name of the author is quoted, the title of the article is often omitted and sometimes it is difficult to identify the journal owing to the manner in which the name is abbreviated. The absence of the year and volume in the case of articles, and the place of publication and name of publisher in the case of books, also renders it difficult for the reader to find the publication. Lack of pagination, too, may lead to a lengthy search, if a volume has no special index.

\section{Institute of Physics}

The annual general meeting of the Institute of Physics was held at the Royal Institution on May 15. After election of the officers and completion of the panel of the Board, it was announced that the following would take office on October 1 next: President, Sir Henry Lyons; Vice-President, Prof. W. L. Bragg ; Honorary Treasurer, Major C. E. S. 